\title{
Using noninvasive ventilation to prevent extubation failure: it is good news, but do we really know what "high risk" means?
}

\author{
Alastair J. Glossop ${ }^{1 *}$ and Antonio M. Esquinas ${ }^{2}$ \\ See related research by Thille et al., http://ccforum.biomedcentral.com/articles/10.1186/s13054-016-1228-2
}

We read with great interest the article by Thille et al. [1] and commend the authors on their work. It is accepted that noninvasive ventilation (NIV) used prophylactically reduces post-extubation respiratory failure, but its impact on reintubation remains contentious [2]. Therefore, the current study, which reports reduced rates of reintubation from $28 \%$ to $15 \%$ in high-risk populations with NIV use, is welcomed.

The study has several limiting factors. It is a prospective before-after study across a long time period, and the authors acknowledge this potential source of bias. There is a large gap between patient cohorts, with data from the original cohort collected between 2005 and 2006 and data from the "after" group collected between 2010 and 2012. No explanation is provided as to why this second period-4 years later-was chosen, which raises concerns regarding selection bias. Additionally, data were collected from a single centre with extensive experience of NIV use, an important factor in the success of NIV use post-extubation [3].

In mitigation, no difference between baseline reintubation rates of low-risk patients was seen between the two groups, and the second patient cohort contained fewer surgical patients-a group known to benefit from postextubation NIV use [4].

We applaud the definition of extubation failure as reintubation within 7 days rather than $48-72 \mathrm{~h}$, as we feel this provides a pragmatic view. It is likely to result in greater numbers of extubation failures and makes the findings more impressive. We also feel that an average

\footnotetext{
* Correspondence: alastair.glossop@sth.nhs.uk

'Department of Critical Care, Sheffield Teaching Hospitals NHS Foundation Trust, Herries Road, Sheffield S5 7AU, UK
}

time of NIV use of $8 \mathrm{~h}$ within the first $24 \mathrm{~h}$ represents a reproducible period for prophylactic use in critical care patients, in whom treatment compliance may be an issue.

We feel that this is an important study and welcome its contribution to the evidence pool. It does, however, raise the important question of what constitutes "high risk" of extubation failure. The authors state that NIV is "pointless" as a prophylactic measure in low-risk populations, but define over $60 \%$ of patients included as high risk; as demands on frontline services increase this figure is surely set to rise. The emergence of high-flow nasal cannula (HFNC) therapy in patients defined as low risk of extubation failure [5] brings an even sharper focus on the need for risk stratification in all ICU patients, and further work is warranted to help guide post-extubation management.

\section{Abbreviations \\ HFNC, high-flow nasal cannula; ICU, intensive care unit; NIV, noninvasive ventilation.}

\section{Authors' contributions \\ AJG and AME constructed, read, and approved the final manuscript.}

\section{Competing interests \\ AJG has received honoraria and speaking fees from Armstrong Medical UK between 2014 and 2016.}

\section{Author details}

Received: 29 March 2016 Accepted: 10 May 2016

Published online: 04 July 2016

\section{References \\ 1. Thille AW et al. Easily identified at-risk patients for extubation failure may benefit from noninvasive ventilation: a prospective before-after study. Crit Care. 2016;20(1):48. \\ 2. Ferrer $\mathrm{M}$ et al. Non-invasive ventilation after extubation in hypercapnic patients with chronic respiratory disorders: randomised controlled trial. Lancet. 2009;374(9695):1082-8.}

\section{Biomed Central}

(c) 2016 The Author(s). Open Access This article is distributed under the terms of the Creative Commons Attribution 4.0 International License (http://creativecommons.org/licenses/by/4.0/), which permits unrestricted use, distribution, and reproduction in any medium, provided you give appropriate credit to the original author(s) and the source, provide a link to the Creative Commons license, and indicate if changes were made. The Creative Commons Public Domain Dedication waiver (http://creativecommons.org/publicdomain/zero/1.0/) applies to the data made available in this article, unless otherwise stated. 
3. Ferrer $\mathrm{M}$ et al. Noninvasive ventilation in severe hypoxemic respiratory failure: a randomized clinical trial. Am J Respir Crit Care Med. 2003;168(12): 1438-44.

4. Glossop AJ et al. Non-invasive ventilation for weaning, avoiding reintubation after extubation and in the postoperative period: a metaanalysis. Br J Anaesth. 2012;109(3):305-14.

5. Maggiore SM et al. Nasal high-flow versus Venturi mask oxygen therapy after extubation. Effects on oxygenation, comfort, and clinical outcome. Am J Respir Crit Care Med. 2014;190(3):282-8.

Submit your next manuscript to BioMed Central and we will help you at every step:

- We accept pre-submission inquiries

- Our selector tool helps you to find the most relevant journal

- We provide round the clock customer support

- Convenient online submission

- Thorough peer review

- Inclusion in PubMed and all major indexing services

- Maximum visibility for your research

Submit your manuscript at www.biomedcentral.com/submit 